\title{
CHALLENGES \& CHANNELS INFLUENCING TRADE UNION IN EMPLOYEE RELATIONS
}

\begin{abstract}
Dr. K. Priya
E-Mail Id: priyakrishan17@gmail.com

Head, Department of Commerce, Vivekanandha College of Arts and Sciences for Women (Autonomous), Elayamplayam, Tiruchengode. Tamil Nadu (India)

Abstract-This study analyses the general challenges faced by trade unions due to globalisation and mainly focus on immigration due to the broadened subject of globalisation and trade unions. Another reason is which we are facing only because of the current increasing asylum seekers in EU countries, particularly in the Nordic and Western European countries. Majority of the latter becomes part of the workforce, after sometime of been registered in the country of destination and are categorised under immigrant workers. An extensive secondary research is carried out, to gather information from varying sources about the subject matter. The findings show that many trade unions are open to have fruitful relationships with immigrant workers and are organising and forming alliances with different immigrant orientated organisations. The success will entirely depend on trade unions' initiatives. Hence, the study made an attempt to study the relationship between trade unions and immigrant workers, and how it can be improved is examined.
\end{abstract}

Key words: Trade Union, Working Condition, Trade Policy

\section{INTRODUCTION}

The origin and development of trade union movements, historical development of trade unions in India, growth of employees and employer's organizations, aims and objectives of trade unions, definition of trade union and trade disputes, recognition of trade unions are discussed in this chapter. Trade Unions play an important role in the settlement of industrial disputes. The trade unions of employees and employers bargain collectively in solving the grievances of the industrial workers. Before going to discuss the role of trade unions in the settlement of industrial disputes it is appropriate to project the historical background for establishing the trade unions. Not only the workers associations, but also employers' associations are regarded as trade unions. The worker's union or association as well as employer's union have to be registered their union under the Indian Trade Union's Act, 1926. Therefore, under the existing law the expression "Trade Union" includes both employers and workers organizations. 14 The origin, growth and development of Trade Union Freedom are determined by multiple concomitant factors and it is not feasible to isolate a single factor from the rest in the context of the reluctant dynamics. In order to have a scientific and rational study of the trade union freedom in India, it is rather imperative to investigate and enquire into various economic, political and legal situations available in some major countries where trade union freedom has now become an integral part of the national main stream. Since, it is a vast subject to deal with the developments of trade unions of each and every country and it is very difficult to do so, the researcher confined to the historical background of the trade unions to the England only.

\section{REVIEW OF LITERATURE}

Rosen and Rosen (1955) on the other hand, found in their study that the membership attitude toward union is influenced by the union policies, programs. Though it is covered in a district organization of machinists have favourable attitudes toward the union policies pertaining to collective bargaining, grievance handling, they did not agree with the union's involvement in politics and the type of political activities that the union was engaged in. About the members' attitudes toward the union, the authors found that about half were satisfied with the union, one-quarter were dissatisfied, and the other quarter was undecided. The attitudes of the members toward various aspects of union are normally studied with a view to assess their implications for membership Further, the membership participation in union affairs is normally studied with a view to assess the nature of union structure and functioning, particularly with a view to assess the extent of democracy or oligarchy in the administration of the union.

Princen \& Kerremans, (2012) choice of strategy depends not only on the importance of specific EU policies or issues for national unions, but it may also depend on differences in resources and traditions of social partnership, corporatism, and conflict, and to what degree trade unions enjoy access to decision-making at the national level. One could suspect that trade unions with a strong national standing might emphasize the importance of working through the national route, whereas those with a weak position may put more weight on collaborating with more resourceful unions such as through the ETUC and ETUFs. In addition, however, unions with a strong national standing may also have greater organizational resources, enabling them to also work through their offices in Brussels.

\section{OBJECTIVES}

$>$ To find out different strategies that is used to enhance healthy relationships and solidarity between trade unions and immigrant workers 


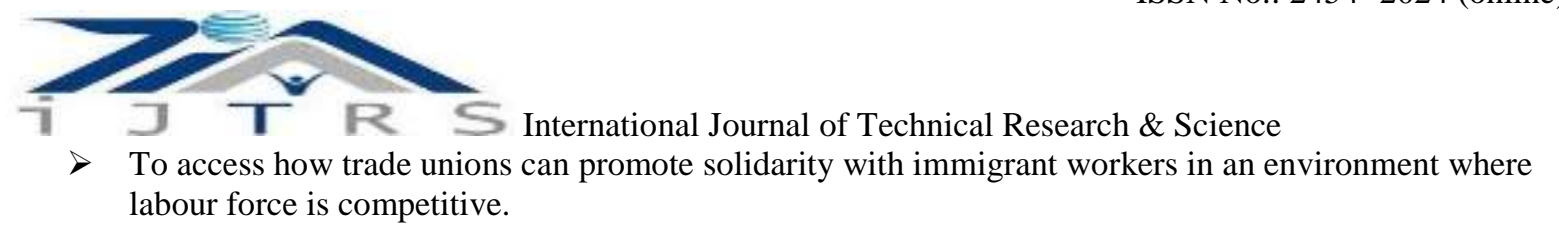

\section{METHODOLOGY}

This study involves all the methods and techniques that will be applied during research; research design data collection, analysis and interpretation. In addition, maintaining the objectivity and abiding to some values related to the control of bias will be exercised in the research work.

\section{DATA COLLECTION}

In data collection, a secondary data method is used to gather information. Therefore, descriptive data will be extracted from secondary sources including; books, articles, journals, periodicals, Government publications such as Labour Force Surveys and NGOs publications and statistics. Due to the fact that this study is based on literature, a secondary data is chosen to suit the purpose of gathering information from existing sources and identify what has been and hasn't been discussed in relation to trade unions and immigrant workers. The diversity of resources will also help to compare the ideas, suggestions and opinions from different sources relating to the subject matter. A sample size will be determined after extensively exploring different sources. Probably, till the data obtained is less significant to the objectives.

\section{CONCLUSION}

The impact of globalisation has contributed unquestionably to the matters related to trade unions. Through globalisation, immigration has escalated which; on the contrary, we would have assumed the opposite due to deindustrialisation in Western Europe. The economic globalisation is inevitable and will continue to steer immigrant workers to move from poor economies to seek opportunities in economically rising countries (though this is not always the case). Immigration may as well result from conflicts and violence, this research focussed on labour migrants assuming that refugees/asylum seekers searching for safer places, majority of them join the labour force of the country in question, sooner or later. Labour mobility has raised concerns for trade unions over the years; we may simply say that they have come from rejecting immigrant workers into accepting them. They now realise that immigrant workers play a crucial role in the workforce and are part and parcel of the working class.

\section{REFERENCE}

[1] Bureau of labour statistics U.S. Department of Labour. 2015 News Release [Online] Available at <http://www.bls.gov/news.release/pdf/union2.pdf [Aocessed 23 September 2015].

[2] Erne, R. (2008) European Unions. Labour's Quest for a Transnational Democracy. Ithaca: Cornell University Press.

[3] Gold, M., Cressey, P. and Léonard, E. (2007) Whatever happened to social dialogue? From partnership to managerialism in the EU employment agenda', European Journal of Industrial Relations 13(1): 7-25.

[4] Hayter S., 2015. Introduction: What future for industrial relations? Special Issue: What Future for Industrial Relations? International Labour Review. [Online] http://onlinelibrary.wiley.com/doi/10.1111/j.1564913X.2015.00220.x/epdf.Accessed 5 October 2015].

[5] Rosen, H., and Rosen; R.A.H., "The Union Member Speaks", Prentice Hall Inc., New York, 1955. 